\title{
SOEKARNO DAN DIPLOMASI INDONESIA
}

\author{
Arifin Suryo Nugroho \\ Program Studi Pendidikan Sejarah Universitas Muhammadiyah Purwokerto
}

\begin{abstract}
Abstrak. Politik luar negeri Soekarno yang lebih condong ke kiri memunculkan kecemburuan dari pihak barat. Inggris mencoba menggabungkan wilayah koloninya di Semenanjung Malaka, Singapura dan Kalimantan Utara menjadi satu dalam Federasi Malaysia. Rencana ini kemudian ditentang oleh Pemerintah Indonesia. Presiden Soekarno berpendapat bahwa Federasi Malaysia merupakan Negara bentukan Inggris, dan hal ini memungkinkan bagi Inggris untuk melakukan kontrol atas Asia Tenggara khususnya Indonesia sebagai tetangga terdekat. Presiden Soekarno mengumumkan Indonesia keluar dari keanggotaan PBB. Presiden Soekarno kemudian membentuk kekuatan baru, yaitu The New Emerging Force (NEFO) sebagai representasi negara-negara dunia ketiga sebagai kekuatan baru untuk melawan kedigdayaan The Old Establsihed Force (OLDEFO) yang berisikan negara-negara maju. Memasuki penghujung tahun 1965 hubungan antara Indonesia semakin erat dengan Cina. Apa yang dilakukan Soekarno ini sebenarnya sebagai salah satu upaya untuk mengimbangi kekuatan militer di dalam politik Indonesia yang semakin menguat.
\end{abstract}

Kata-kata kunci: Soekarno, diplomasi Indonesia, NEFO, GANEFO

Abstract. The foreign policy of Soekarno looking at the left makes the jealousy of the Western countries. England tries to unite all Malay colonies, Malay Peninsula, Singapore, and North Borneo becoming a Malay federation. This plan then is refuted by Indonesian. Soekarno argues that the federation formed by England and this will lead a control upon Southeast Asia including Indonesia as nearest neighbourhood country. Soekarno announces that Indonesia will leave from the United Nations. He forms the new power of The New Emerging Force (NEFO) as the representation of the third world resisting The Old Established Force (OLDEFO) consisting of the developed countries. Soekarno approaches the communist block as an effort to equalize the military power in the Indonesian politic.

Keywords: Soekarno, Indonesian diplomatic, NEFO, GANEFO

Orang sering mengatakan kepada kita, bahwa kolonialisme sudah mati. Janganlah kita mau tertipu atau terninabobokan olehnya! Saya berkata kepada Tuan-tuan, kolonialisme belumlah mati. Bagaimana kita dapat mengatakan ia telah mati selama daerah-daerah yang luas di Asia dan Afrika belum lagi merdeka! (petikan pidato Presiden Soekarno di KAA 1955)

Saat itu kondisi keamanan dunia masih belum stabil pasca berakhirnya perang dunia kedua, kondisi semakin diperparah dengan munculnya perang dingin antara dua blok yang saling berseberangan yaitu Blok Barat yang dipimpin oleh Amerika Serikat, dan Blok Timur yang dipimpin oleh Uni Sovyet. Kedua kekuatan besar yang saling berlawanan baik secara ideologis maupun kepentingan tersebut terus berlomba-lomba untuk membangun senjata modern, sehingga situasi dunia pada saat itu selalu diliputi oleh kecemasan akan terjadinya perang nuklir. Kondisi tersebutlah yang mendorong negara-negara yang baru merdeka itu untuk menggalang persatuan dan mencari jalan keluar demi meredakan ketegangan dunia dan memelihara perdamaian.

\section{POLITIK LUAR NEGERI INDONESIA}

Proklamasi Indonesia yang diproklamirkan oleh Soekarno dan Moh. Hatta telah membawa bangsa ini menuju suatu era yang baru di mana Indonesia resmi menjadi sebuah negara. Sebagai sebuah negara yang baru tentu saja Indonesia membutuhkan pengakuan dari negara lain bahwa nega- 
ra Indonesia sudah berdiri dan siap untuk menjadi anggota dari komunitas internasional. Selain itu juga pada pasca kemerdekaan Indonesia dan berakhirnya Perang Dunia II, konstelasi politik dunia terbagi menjadi kekuatan besar antara Blok Barat (AS) dan Blok Timur (Soviet). Banyak negaranegara di dunia ini pun tak lepas dari arus konstelasi tersebut, mereka berlomba untuk menjadi aliansi Blok Barat maupun Blok Timur.

Periode ini dikenal sebagai era perang dingin, yang menampilkan persaingan sengit antara kedua blok di berbagai bidang kehidupan: koalisi militer; ideologi, psikologi, dan telik sandi; militer, industri, dan pengembangan teknologi; pertahanan, perlombaan nuklir dan persenjataan. Konflik antara kedua blok ini lantas menyebar ke seluruh dunia ketika AS membangun pertahanan terhadap komunisme dengan membentuk sejumlah aliansi dengan berbagai negara, terutama negara di Eropa Barat, Timur Tengah, dan Asia Tenggara. Meskipun kedua negara adikuasa itu tidak pernah bertempur secara langsung, konflik di antara keduanya secara langsung ataupun tidak langsung telah menyebabkan berbagai perang atau ketegangan, baik dalam hubungan antar bangsa maupun di dalam bangsa-bangsa. Konflik antara dua negara adikuasa itu memicu perang lokal seperti Perang Korea, invasi Soviet terhadap Hongaria dan Cekoslovakia dan Perang Vietnam. Perang dingin juga memberi kontribusi kediktatoran di Yunani dan Amerika Selatan, menimbulkan krisis rudal Kuba dan krisis Timur Tengah. Dampak lainnya adalah terbaginya Jerman menjadi dua bagian yaitu Jerman Barat dan Jerman Timur yang dipisahkan oleh tembok Berlin. Posisi ini cukup membuat Indonesia mengalami masa-masa sulit.

Sementara itu agresi Belanda yang ingin kembali menjajah pasca kemerdekaan, Indonesia dihadapkan pada situasi yang dilematis. Kelompok kiri ingin bangsa ini bergabung dengan blok Komunis yang sangat anti Barat, untuk memperkuat perjuangan melawan Belanda yang merupakan anggota dari blok Barat. Sementara para pemimpin nasionalis seperti Hatta dan Sjahrir, tid- ak ingin Indonesia dikuasai komunis. Inilah alasan kenapa akhirnya pemerintah mengambil jalan tengah, yakni tidak memihak kepada blok manapun (Legge, 1972:255-276).

Indonesia berusaha konsisten dengan prinsip kemanusiaan yang adil dan beradab dalam pergaulan antar bangsa. Prinsip yang menjunjung tinggi kemerdekaan sebagai hak setiap bangsa dan warganya, serta prinsip yang menekankan koeksistensi damai yang secara aktif "ikut melaksanakan ketertiban dunia yang berdasarkan kemerdekaan, perdamaian abadi, dan keadilan sosial." Prinsip kemanusiaan Indonesia termaktub dalam Pancasila menjadi sintesis ajaran Declaration of American Independence dan Manifesto Komunis.

Dalam sebuah pidato Soekarno di PBB, yang diberi tajuk "To Build the World a New", Soekarno menyangkal pendapat filsuf Bertrand Russel, yang membagi dunia ke dalam dua poros ajaran itu. "Maafkan Lord Russel. Saya kira tuan melupakan adanya lebih daripada seribu juta rakyat, rakyat Asia dan Afrika, dan mungkin pula rakyat-rakyat Amerika Latin, yang tidak menganut ajaran Manifesto Komunis ataupun Declaration of American Independence." Selanjutnya, ia katakan bahwa Indonesia tidak dipimpin oleh kedua paham itu, tidak mengikuti konsep liberal dan komunis. "Dari pengalaman kami sendiri dan dari sejarah kami sendiri tumbuhlah sesuatu yang lain, sesuatu yang jauh lebih cocok." Lantas dia simpulkan, "Sesuatu itu kami namakan Pancasila. Gagasangagasan dan cita-cita itu, sudah terkandung dalam bangsa kami. Telah timbul dalam bangsa kami selama dua ribu tahun peradaban kami dan selama berabad-abad kejayaan bangsa, sebelum imperialisme menenggelamkan kami pada suatu saat kelemahan nasional.” (Soekarno, 1989:63-64).

Dalam situasi politik perang dingin dan memperjuangkan ko-eksistensi damai, Mohammad Hatta merumuskan arah politik luar negeri Indonesia yang bebas aktif, sebagaimana terkenal dalam buku tulisannya yang berjudul Mendayung Di antara Dua Karang. Makna politik luar negeri sep- 
erti yang pernah diutarakan Bung Hatta pada pidato pertamanya sebagai Perdana Menteri Republik Indonesia di hadapan Badan Pekerja Komite Nasional Indonesia Pusat (BP-KNIP) tanggal 2 September 1948 adalah sebagai berikut:

Bebas artinja menentukan djalan sendiri, tidak terpengaruh oleh pihak manapun sedangkan aktif artinja menudju perdamaian dunia dan bersahabat dengan segala bangsa..." "Pemerintah berpendapat bahwa pendirian jang harus kita ambil ialah supaja kita djangan mendjadi objek dalam pertarungan politik internasional, melainkan kita harus tetap mendjadi subjek jang berhak menentukan sikap kita sendiri, berhak memperdjoangkan tudjuan kita sendiri, jaitu Indonesia Merdeka seluruhnja.(Hatta, 1948:29).

Sebelum itu, Sjahrir dalam pidatonya di depan Asian Relations Conference di New Delhi, 25 Oktober 1947 mengatakan, "dunia tampaknya memaksa kita membuat pilihan antara kekuatan yang sekarang saling bermusuhan, antara blok Anglo-Saxon dan blok Soviet Rusia. Benarlah sikap kita yang menolak untuk dipaksa. Kita mencari wujud internasional yang sesuai dengan kehidupan intern kita dan kita tidak ingin terperangkap dalam sistem-sistem yang tidak cocok dengan kita dan tentu saja tidak ke dalam sistem yang saling bermusuhan dengan tujuan kita..."(Tim Balai Pustka, 1946).

Dari ucapan ketiga tokoh yang menentukan politik luar negeri pada awal berdirinya Republik Indonesia, cukup jelas bahwa sedari awal negara ini berdiri telah diletakkan dalam politik nonblok, jauh sebelum gerakan nonblok sendiri muncul di arena politik internasional, walaupun istilah nonblok pada waktu itu belum dipakai.

Politik luar negeri bebas dan aktif ini sudah merupakan suatu politik yang diterima secara mantap oleh masyarakat Indonesia. Ketika tahun 1951 Menteri Luar Negeri Ahmad Subardjo dan Duta Besar Amerika Merle Cochran menandatangani perjanjian kerjasama keamanan dengan Amerika
Serikat terkait dengan Mutual Security Act (MSA), terjadi krisis politik di Indonesia yang menjatuhkan kabinet Sukiman (Loebis, 1992:254). Kerjasama tersebut dinilai sangat merugikan politik luar negeri bebas aktif yang dianut Indonesia. Kabinet Sukiman dituduh telah memasukkan Indonesia ke dalam Blok Barat.

Salah satu ciri ekspresi politik bebas aktif adalah politik nonblok. Dalam hal ini, Indonesia bebas memilih jalan dalam perpolitikan dunia. Tidak ada tekanan baik dalam maupun luar. Indonesia tidak kemudian jatuh ke tangan Blok Barat maupun Blok Timur. Indonesia mencoba untuk berdiri di tengah-tengah (di antara dua karang) dan tidak memihak AS maupun Soviet. Karena jika memihak salah satunya akan melunturkan semangat dan makna dari 'bebas' itu sendiri.

\section{DARI KAA KE GNB: PANGGUNG SOE- KARNO}

Januari 1950, Presiden Soekarno melakukan kunjungan internasionalnya yang pertama sebagai Presiden Republik Indonesia, yaitu mengadakan kunjungan ke India, Pakistan, dan Birma (Nugroho, 2010:145-148). India memiliki hubungan sejarah yang panjang dengan Indonesia. India juga salah satu negara pertama yang mengakui kemerdekaan Indonesia. Presiden Sukarno diundang ke India dalam rangka perayaan Kemerdekaan Negara India dari kolonialis Inggris. Fatmawati sebagai Ibu Negara masuk dalam rombongan lawatan ke India itu. Mereka berangkat tanggal 23 Januari 1950. Dalam kunjungan itu, Presiden Sukarno menjalin komunikasi intensif dengan Presiden India, Rajendra Prasad dan PM India Jawaharlal Nehru. Soekarno dan Nehru dikenal dua tokoh yang memiliki hubungan persahabatan sangat baik. Soekarno pernah menulis surat pada Nehru, "India dan rakyatnya terikat erat pada kami dengan darah dan kebudayaan. Hubungan ini telah terjalin dari awal tercatatnya sejarah. Kata India juga akan selalu ada dalam hidup kami. Sebagian kata itu merupakan rangkaian hu- 
ruf pertama yang kami pilih untuk menamai bangsa dan negara ini." Soekarno dan Jawaharlal Nehru merupakan pelopor kekuatan besar Asia saat itu.

Selain India, Pakistan juga paling gencar menyokong dan melantangkan pengakuan terhadap kemerdekaan Indonesia. Salah satu bentuknya adalah ketika Gubernur Jenderal Pakistan, Muhammad Ali Jinnah, memboikot pesawatpesawat Belanda yang hendak transit di Pakistan. Tahun 1947, Ali Jinnah melarang terbang atau mendaratnya pesawat Belanda di Pakistan, ketika sedang menghimpun kekuatan untuk persiapan agresi militer pertama (21 Juli-5 Agustus 1947). Dukungan dan persahabatan diantara kedua negara inilah yang mendorong Soekarno melakukan lawatan internasional keduanya ke Pakistan. Dalam kunjungan Presiden Soekarno ke Birma (Myanmar), ia dan PM Birma $\mathrm{U} \mathrm{Nu}$ menandatangani pernyataan bersama, yang isinya Pemerintah Birma mendukung Indonesia sepenuhnya atas perjuangan memasukkan Irian Barat ke wilayah Indonesia.

Pandangan para pemimpin Asia itu mengenai suatu masyarakat baru, negara-negara yang bebas dan baru merdeka, menjadi faktor penting terselenggaranya Konferensi Asia Afrika 1955 dan pergerakan Nonblok, konferensi yang mendapat sorotan dunia dalam hal diplomasi internasional saat itu. Sebelum Konferensi Asia Afrika dilaksanakan, terlebih dahulu diadakan konferensi pendahuluan sebagai persiapan. Konferensi pendahuluan tersebut yang pertama adalah Konferensi Kolombo. Konferensi ini diselenggarakan di Kolombo, ibu kota negara Sri Lanka pada tanggal 28 April s.d. 2 Mei 1954. Konferensi dihadiri oleh lima orang perdana menteri yakni Perdana Menteri Pakistan Muhammad Ali Jinnah, Perdana Menteri Sri Lanka Sir John Kotelawala, Perdana Menteri Birma (Myanmar) U Nu, Perdana Menteri Indonesia Ali Sastroamijoyo, dan Perdana Menteri India Jawaharlal Nehru.

Konferensi Kolombo membahas masalah Vietnam, sebagai persiapan untuk menghadapi Konferensi di Jenewa Swiss. Konferensi Jenewa yang berlangsung 26 April-20 Juli 1954 itu bertujuan mencoba menemukan cara menyatukan Vietnam dan mendiskusikan kemungkinan memulihkan perdamaian di Indocina. Di samping itu Konferensi Kolombo secara aklamasi memutuskan akan mengadakan Konferensi Asia Afrika dan pemerintah Indonesia ditunjuk sebagai penyelenggaranya. Kelima negara yang wakilnya hadir dalam Konferensi Kolombo kemudian dikenal dengan nama Pancanegara. Kelima negara itu disebut sebagai negara sponsor.

Konferensi pendahuluan kedua yakni Konferensi Bogor, diselenggarakan di Bogor pada tanggal 22-29 Desember 1954. Konferensi itu dihadiri pula oleh perdana menteri negara-negara peserta Konferensi Kolombo. Konferensi Bogor memutuskan antara lain; konferensi Asia Afrika akan diselenggarakan di Bandung pada bulan 1824 April 1955, penetapan tujuan KAA dan menetapkan negara-negara yang akan diundang sebagai peserta Konferensi Asia Afrika, hal-hal yang akan dibicarakan dalam Konferensi Asia Afrika, pemberian dukungan terhadap tuntutan Indonesia mengenai Irian Barat.

Konferensi Kolombo dan Konferensi Bogor sebagai pertemuan pembuka yang menentukan kesuksesan penyelenggaraan KAA, diakui Soekarno dalam pidato saat membuka konferensi di Bandung itu. Ia katakan bahwa konferensi Kolombo dan konferensi Bogor adalah tonggak penting dari penyelenggaraan KAA, "Kalau kita bendak mencari pelopor daripada pertemuan besar kita ini, kita harus menengok ke Colombo, ibu kota Sri Lanka yang merdeka, dan melihat ke Konferensi Lima Perdana Menteri, yang diadakan di sana dalam tahun 1954. Dan Konferensi Bogor dalam bulan Desember 1954 menunjukkan bahwa jalan di hadapan kita telah siap untuk persatuan AsiaAfrika, dan Konferensi, di mana saya mendapat kehormatan mengucapkan selamat datang kepada Tuan-tuan pada hari ini adalah penjelmaan, realisasi, daripada persatuan itu."(Soekarno, 1955).

Konferensi Asia Afrika membicarakan halhal yang menyangkut kepentingan bersama nega- 
ra-negara di Asia dan Afrika, terutama kerja sama ekonomi dan kebudayaan, serta masalah kolonialisme dan perdamaian dunia. Kerja sama ekonomi dalam lingkungan bangsa-bangsa Asia dan Afrika dilakukan dengan saling memberikan bantuan teknik dan tenaga ahli. Dalam konferensi tersebut ditegaskan juga pentingnya masalah perhubungan antarnegara karena kelancaran perhubungan dapat memajukan ekonomi melalui pertukaran delegasi dagang. Konferensi Asia Afrika menyokong sepenuhnya prinsip dasar hak asasi manusia yang tercantum dalam Piagam PBB. Konferensi mendukung usaha untuk melenyapkan rasialisme dan diskriminasi warna kulit di mana pun di dunia ini. Konferensi juga menyatakan bahwa kolonialisme dalam segala bentuk harus diakhiri dan setiap perjuangan kemerdekaan harus dibantu sampai berhasil. Juga diserukan agar percobaan senjata nuklir dihentikan dan masalah perdamaian juga merupakan masalah yang sangat penting dalam pergaulan internasional. Demi perdamaian pula, konferensi menganjurkan agar negara yang memenuhi syarat segera dapat diterima menjadi anggota PBB.

Konferensi Asia Afrika membawa pengaruh yang besar bagi solidaritas dan perjuangan kemerdekaan bangsa di Asia dan Afrika. KAA adalah perintis dalam membina solidaritas bangsabangsa dan merupakan titik tolak untuk mengakui kenyataan bahwa semua bangsa di dunia harus dapat hidup berdampingan secara damai. KAA mendorong perjuangan kemerdekaan bangsa di dunia pada umumnya serta di Asia dan Afrika khususnya.

Selain membawa pengaruh bagi solidaritas dan perjuangan kemerdekaan bangsa di Asia dan Afrika, Konferensi Asia Afrika juga menimbulkan dampak yang penting dalam perkembangan dunia pada umumnya. Negara-negara besar seperti Australia dan Amerika Serikat mulai berusaha menghapuskan diskriminasi ras di negaranya. Konferensi Asia Afrika juga mampu menjadi penengah dua blok yang saling berseteru sehingga dapat mengurangi ketegangan akibat Perang Dingin dan mencegah terjadinya perang terbuka.
Konferensi Asia Afrika juga meletakkan prinsip dasar bagi perdamaian dunia dan memberikan inspirasi bagi pembentukan Gerakan Nonblok. Gerakan Non-Blok (Non-Aligned) telah dicetuskan di Colombo tahun 1954, dipupuk di KAA Bandung, dan lahir di Beograd tahun 1961. Dalam kenyataannya, konferensi Bandung berhasil menyebarkan benih-benih Non-Blok sebagai penegasan kedaulatan negara berkembang dalam hubungan internasional.

Gerakan Non-Blok yang menemukan momentumnya pada KTT Non-Blok 1961, diselenggarakan di Beograd Yugoslavia dan diikuti oleh 25 negara dari Asia, Afrika, Eropa, dan Amerika Latin. Pemimpin penting yang ada di belakang KTT Nonblok itu adalah Tito (Yugoslavia), Nasser (Mesir), Sukarno (Indonesia), Nehru (India), dan Nkrumah (Ghana). Kwame Nkrumah muncul di arena politik Ghana pada tahun 1957 hingga digulingkan junta militer pada tahun 1966. Dalam kepemimpinan yang singkat ia muncul sebagai salah satu tokoh Afrika yang mempunyai peran besar dalam menggerakkan Non-Blok di Afrika. Gagasan Pan-Afrika yang diidam-idamkannya menjelma dalam bentuk Organization of African Unity $(O A U)$ yang menerima Non-Blok sebagai satu keharusan pokok untuk menjadi anggota.

Presiden Soekarno dalam pidatonya pada KTT Non-Blok di Beograd dengan gamblang menggambarkan apa yang dimaksud dengan politik Non-Blok. Berikut Soekarno menjelaskan:

Janganlah ada salah paham. Nonblok bukanlah netralitas. Ini bukan sikap purapura alim atau munafik dari seseorang yang menjauhkan diri dari penyakit menular. Politik Nonblok bukanlah politik mencari posisi netral jika ada peperangan, politik Nonblok bukanlah politik netral tanpa warna sendiri. Menjadi Nonblok tidak berarti menjadi penyangga antar dua blok raksasa. Nonblok adalah pengabdian yang aktif bagii cita-cita luhur kemerdekaan yang berpegang teguh pada 
perdamaian, keadilan sosial dan kebebasan untuk merdeka (Sabir, 1990:21).

Bagi Soekarno tentang Non-Blok itu relevan dengan pemikiran Nehru dan Tito. Mereka menegaskan bahwa politik Non-Blok yang telah dianut pemerintah mereka masing-masing dan yang sedang dijalankan mereka, bukanlah politik netral, netralisme ataupun politik pasif, tetapi adalah politik aktif, positif, dan konstruktif yang berusaha untuk menciptakan satu perdamaian bersama sebagai satu-satunya dasar bagi keamanan bersama (Sabir, 1990:20-21).

Politik Nonblok tidak netral, tidak pasif dan negatif, bahkan aktif dan positif. Pandit Nehru dalam pidatonya pada KTT Non-Blok I menyataka, "Kita menyebut diri kita konferensi negara-negara Non-Blok. Sekarang perkataan Non-Blok dapat diberi bermacam interpretasi, tetapi pada umumnya kata itu dipakai dan dibuat kurang lebih dengan pengertian Non-Blok terhadap kekuatan blok dunia. Non-Blok juga memiliki arti yang negatif, tetapi jika anda memberinya konotasi positif, dia akan berarti negara-negara yang berkeberatan terhadap pengelompokan blok yang bertujuan perang, aliansi militer dan sebagainya. Oleh karena itu kita jauh dari hal ini dan kita berminat untuk melemparkan beban kita untuk menciptakan perdamaian. Dalam kenyataannya apabila timbul krisis yang menyangkut kemungkinan perang, justru oleh karena kita Non-Blok hendaknya mendorong kita bertindak, mendorong kita berpikir dan mendorong kita untuk merasakan bahwa kini lebih dari sebelumnya terserah pada kita apa yang dapat kita lakukan untuk mencegah malapetaka datang menimpa kita." (Sabir, 1990:22-23).

Gerakan Non-Blok memang tidak mempunyai kekuatan ekonomi apalagi kekuatan militer. Gerakan Non-Blok pada dasarnya lebih banyak merupakan kekuatan moral, namun dimensi kegiatannya mencakup masalah global. Non-Blok giat memperjuangkan politik apartheid yang merupakan aspirasi rakyat Afrika, memperjuangkan anti zionisme yang merupakan aspirasi negara-negara Arab, dan giat menentang kolonialisme dan imperialisme yang saat itu menyangkut masalah dua pertiga penduduk dunia.

\section{PENUTUP}

Beberapa tahun berlalu setelah Indonesia mengikrarkan diri sebagai negara yang memiliki pandangan politik luar negeri bebas aktif, politik luar negeri Soekarno mulai ia arahkan ke kiri, dan hal ini memunculkan kecemburuan dari pihak barat. Pada tahun 1961, Inggris mencoba menggabungkan wilayah koloninya di Semenanjung Malaka, Singapura dan Kalimantan Utara menjadi satu dalam Federasi Malaysia. Rencana ini kemudian ditentang oleh Pemerintah Indonesia. Presiden Soekarno berpendapat bahwa Federasi Malaysia merupakan Negara bentukan Inggris, dan hal ini memungkinkan bagi Inggris untuk melakukan kontrol atas Asia Tenggara khususnya Indonesia sebagai tetangga terdekat. Ketegangan hubungan Indonesia-Malaysia semakin ditegaskan oleh Presiden Soekarno. Pada tanggal 7 Januari 1965, Presiden Soekarno mengumumkan Indonesia keluar dari keanggotaan PBB. Presiden Soekarno kemudian membentuk kekuatan baru, yaitu The New Emerging Force (NEFO) sebagai representasi negara-negara dunia ketiga sebagai kekuatan baru untuk melawan kedigdayaan The Old Establsihed Force (OLDEFO) yang berisikan negara-negara maju.

Memasuki penghujung tahun 1965 hubungan antara Indonesia semakin erat dengan Cina. Apa yang dilakukan Soekarno ini sebenarnya sebagai salah satu upaya untuk mengimbangi kekuatan militer di dalam politik Indonesia yang semakin menguat. Pada masa ini pula kesehatan Presiden Soekarno mulai mengalami penurunan dan menjadi jalan pembuka bagi munculnya revolusi untuk menggantikan posisi Presiden Soekarno sebagai penguasa tunggal Indonesia. 


\section{DAFTAR RUJUKAN}

Loebis, A.B. 1992. Kilas Balik Revolusi: Kenangan, Pelaku, dan Saksi. Jakarta: UI Press.

Nugroho, A.S. 2010. Fatmawati Sukarno: The First Lady. Yogyakarta: Ombak.

Legge, J.D. 1972. Sukarno Sebuah Biografi Politik. Jakarta: Pustaka Sinar Harapan.

Sabir, M. 1990. Quo Vadis Nonblok. Jakarta: CV Haji Masagung.

Hatta, M. 1948. Mendajung Dua Karang: Keterangan Pemerintah Diutjapkan Oleh Drs. Mohammad Hatta Dimuka Sidang BPKNIP. Yogyakarta: Kementerian Penerangan Republik Indonesia.

Soekarno. 1989. Pancasila dan Perdamaian Dunia. Jakarta: CV Haji Masagung.

Tim Balai Pustaka. 1946. Kumpulan Pidato Presiden Soekarno, Wakil Presiden Drs. Moh. Hatta, Perdana Menteri Sutan Sjahrir. Jakarta: Balai Pustaka. 